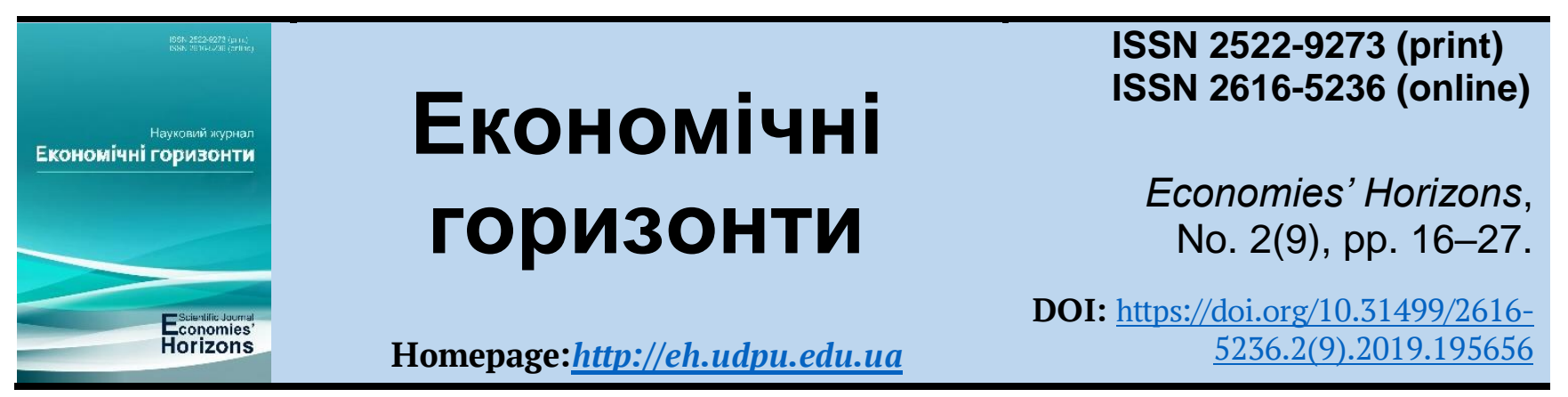

UDC 332.122:332.142.6

\title{
Mechanisms of elements interaction in the system of ecological and economic regional competitive advantages
}

\author{
Nataliia O. Andrusyak ${ }^{1}$, Cand. Ec. Sc., Associate Professor
}

Received: 12 April 2019

Accepted: 17 May 2019
Andrusyak, N. O. (2019), "Mechanisms of elements interaction in the system of ecological and economic regional competitive advantages", Economies' Horizons, no. 2(9), pp. 16-27, doi: https://doi.org/10.31499/2616-5236.2(9).2019.195656.

\begin{abstract}
The purpose of the research. The purpose of the article is to build a conceptual scheme of the interaction of structural elements in the system of ecological and economic competitive potential of the region to improve the mechanisms of interaction of elements in the system of ecological and economic competitive advantages of the regions. Methodology. The general scientific methods, including generalization, aggregation, comparison, are used in the research - to analyze the views of scientists on the subject of study of ecological and economic competitive advantages of regions; and special methods, such as analysis and synthesis - to formulate basic categories of research, expert evaluation to build a system of factors of environmental and economic competitiveness of the regions of Ukraine, graphic representation - to visualize the results of the research. Results. The approaches to determining the competitive advantages of the regions existing in the scientific literature are analyzed, and it is estimated that the absolute majority of authors in their research consider the view of the competitiveness of the regions by the system. The system is proposed to consider the competitive potential of the region, and the competitiveness of the regions as a system characteristic. From this position, the main elements of ecological and economic competitive potential are identified, in particular: the actual competitive potential of the region, sources and factors of regional competitiveness, ecological and economic competitive advantages, competitive positions and competitive status of the region. The characteristics of the components of the ecological and economic competitive potential of the regions, allocated in accordance with the logic, are presented, as well as the substantiated indicators that are proposed to be used for the evaluation of the economic and environmental components of the potential. The proposed classification of factors of ecological and economic competitiveness of Ukrainian regions, which distinguishes them from the existing ones, is a comprehensive reflection of all groups of factors that determine the ecological and economic competitive potential of regions, as well as the possibility of ranking the factors of competitiveness by the degree of economic and environmental impact. In order to assess the degree of influence of the selected factors on the ecological and economic competitiveness of the regions, an expert evaluation was conducted organized in a selective manner. Leading specialists (civil service experience of at least 5 years) of the regional authorities, namely the Regional State Administrations of the regions of Ukraine, were selected as experts, who were invited to
\end{abstract}

${ }^{1}$ Cherkasy Bohdan Khmelnytsky National University; Associate Professor at the Department of Enterprise Economics, Accounting and Auditing; ORCID ID: https://orcid.org/0000-0001-8939-7750; e-mail: andrusiak.n@gmail.com. 
fill in the developed questionnaire form. The above classification has revealed that environmental and economic competitiveness factors can influence at the regional level the living conditions of citizens, the activities of organizations and ensure effective public administration, while the influence on some factors is limited by established state and regional powers. The stages of transformation of sources of competitive advantage into positive dynamics of indicators of competitiveness of the region are highlighted, appropriate procedures and tools for their implementation are developed. The conceptual scheme of interaction of elements in the system of ecological and economic competitive potential of the region is developed. Practical meaning. Building a conceptual scheme of interaction of structural elements in the system of ecological and economic competitive potential of the region allows to trace how the ecological and economic competitive potential of the region is transformed into sources of ecological and economic competitive advantages by means of economic and ecological factors of regional competitiveness, - economic competitive advantages on which the competitive position of the region is based. Prospects for further research have established the rationale for strategic and tactical tools for managing the region's ecological and economic competitiveness.

Keywords: ecological and economic competitiveness of the region, ecological and economic competitive potential of the region, ecological and economic competitive advantages of the region, sources of competitive advantages.

JEL Classification: O18, O33, O49, R11, R13.

Number of references: 10; number of tables: 2; number of figures:3; number of formulas: $\mathbf{0 .}$

\title{
Механізми взаємодії елементів в системі еколого-економічних конкурентних переваг регіонів
}

\author{
Наталія Олександрівна Андрусяк ${ }^{1}$, к. е. н., доцент
}

Стаття надійила: 12.04.2019 Стаття прийнята: 17.05.2019
Andrusyak N. O. Mechanisms of elements interaction in the system of ecological and economic regional competitive advantages. Економічні горизонти. 2019. № 2(9). C. 16-27.DOI: 10.31499/2616-5236.2(9).2019.195656.

Анотація. Мета дослідження. Метою статті є побудова концептуальної схеми взаємодії структурних елементів в системі еколого-економічного конкурентного потенціалу регіону для удосконалення механізмів взаємодії елементів в системі еколого-економічних конкурентних переваг регіонів. Методологія. У досліджені застосовані загальнонаукові методи, зокрема узагальнення, агрегування, порівняння - для аналізу поглядів науковців щодо предмету дослідження еколого-економічних конкурентних переваг регіонів; та спеціальні методи, зокрема аналіз та синтез - для формулювання базових категорій дослідження, експертне оцінювання - для побудови системи факторів еколого-економічної конкурентоспроможності регіонів України, графічне зображення - для візуалізації результатів дослідження. Результати. Проаналізовані існуючі в науковій літературі підходи до визначення конкурентних переваг регіонів, за оцінкою яких встановлено, що абсолютна більшість авторів у своїх дослідженнях виходять 3 позиції бачення конкурентоспроможності регіонів системою. Запропоновано системою вважати конкурентний потенціал регіону, а конкурентоспроможність регіонів системною характеристикою. 3 цієї позиції визначені основні елементи еколого-економічного конкурентного потенціалу, зокрема: власне конкурентний потенціал регіону, джерела і фактори регіональної конкурентоспроможності, еколого-економічні конкурентні переваги, конкурентні

\footnotetext{
${ }^{1}$ Черкаський національний університет імені Богдана Хмельницького; доцент кафедри економіки підприємства, обліку і аудиту; ідентифікатор ORCID: https://orcid.org/0000-0001-8939-7750; e-mail: andrusiak.n@gmail.com.
} 
позиції та конкурентний статус регіону. Наведена характеристика виділених відповідно до логіки дослідження складових еколого-економічного конкурентного потенціалу регіонів, та обгрунтовані показники, що пропонується застосовувати для оцінювання економічної та екологічної складових потенціалу. Запропонована класифікація факторів еколого-економічної конкурентоспроможності регіонів України, відмінною рисою якої від вже існуючих, $\epsilon$ комплексне відображення всіх груп факторів, що визначають еколого-економічний конкурентний потенціал регіонів, а також передбачена можливість ранжування факторів конкурентоспроможності за ступенем впливу на економічну та екологічну складові. Для оцінки ступеню впливу виділених факторів на еколого-економічну конкурентоспроможність регіонів проведене експертне оцінювання, організоване вибірковим способом. В якості експертів були обрані провідні спеціалісти (стаж державної служби не менш, ніж 5 років) регіональних органів влади, а саме Обласних державних адміністрацій регіонів України, яким було запропоновано заповнити розроблену форму анкети. Наведена класифікація дозволила виявити, що фактори еколого-економічної конкурентоспроможності можуть впливати на регіональному рівні на умови життєзабезпечення громадян, діяльності організацій і забезпечувати ефективне державне управління, при цьому вплив на деякі фактори обмежений встановленими державними i регіональними повноваженнями. Виділені етапи перетворення джерел конкурентної переваги в позитивну динаміку показників конкурентоспроможності регіону, розроблені відповідні процедури та інструменти їх реалізації. Розроблено концептуальну схему взаємодії елементів в системі еколого-економічного конкурентного потенціалу регіону. Практичне значення. Побудова концептуальної схеми взаємодії структурних елементів в системі екологоекономічного конкурентного потенціалу регіону дозволяє простежити, яким чином екологоекономічний конкурентний потенціал регіону за допомогою економічних та екологічних факторів регіональної конкурентоспроможності перетворюється в джерела екологоекономічних конкурентних переваг, і як з цих джерел формуються власне еколого-економічні конкурентні переваги, на яких засновані конкурентні позиції регіону. Перспективами подальщих досліджень встановлено обгрунтування стратегічного та тактичного інструментарію управління еколого-економічною конкурентоспроможністю регіону.

Ключові слова: еколого-економічна конкурентоспроможність регіону, екологоекономічний конкурентний потенціал регіону, еколого-економічні конкурентні переваги регіону, джерела конкурентних переваг.

Кількість джерел: 10; кількість таблиць: 2; кількість рисунків: 3; кількість формул:0.

\section{Introduction.}

Market mechanisms cause movement of production factors towards high productive and competitive sectors of economics, which is accompanied by strengthening of the competitive struggle in the international space, thus a problem of competitive advantages formation and realization becomes acute for every state. Weakening of Ukraine's national sovereignty and decrease of the state role as a regulator under the conditions of power decentralization are accompanied by the priorities shift in solving the tasks for effective realization of the ecological and economic competitive advantages to the regional level.
Whereas some regions successfully form and realize their competitive advantages at the interregional market, correcting their regional interests within the restrictions set by the national institutes, the other ones possess the sources of the competitive advantages, but they do not form real competitive advantages from them due to the subjective reasons. In the first case regions demonstrate rational usage of the available resources, effectively applying market regulators, while in the second case it is necessary to have a complete modernization of instruments in the process of formation and realization of the regions' competitive advantages. 
Problem statement. Because of the stated above it is essential for the theory and practice to determine the specific features for transformation of the competitive advantages sources into positive dynamics of the regional competitiveness level. In particular it is necessary to improve the mechanism of elements interaction in the system of the region's ecological and economic competitive advantages. Solution of the stated problem has a significant meaning for raising competitiveness of Ukraine's regions.

\section{Literature review.}

The processes of competitive advantages formation and realization at the regional level have been explored by many foreign and Ukrainian scientists. However it is necessary to state that in their researches the absolute majority of authors consider from the viewpoint of the region's competitiveness system. Namely, P. Yu. Bilenkyi (Bilenkyi, 2005, p. 48), O. P. Romanko (2015), Z. V. Gerasymchuk and L. L. Kovalska (2008) define competitiveness as a system of properties allowing a region to effectively provide a competitive struggle for reaching the set goals. Such authors like K. M. Chertok and T. P. Goncharenko (2013), M. I. Nazarov (2013) explore competitiveness of regions as the amount of interconnected elements. It is certain, that competitiveness as a complex economic category is characterized by a number of system attributes, however from the viewpoint of strategic and tactic management of the regions' ecological and economic competitiveness one should support the alternative position offered by S. N. Rastovtseva and N. A. Grineva (2014). They believe that not only competitiveness, but also competitive potential of a region should be considered as a system.

\section{Methods.}

The methods used in the research are the following: general scientific methods, in particular generalization, aggregation, comparison - to analyze the scientists' views concern- ing the research subject of the regions' ecological and economic competitive advantages; and special methods, namely analysis and synthesis - to formulate basic research categories, expert evaluation - to make a system of factors of the ecological and economic competitiveness of Ukraine's regions.

\section{Research objectives.}

The objective of the article is to form a conceptual scheme of the structural elements interaction in the system of the ecological and economic competitive potential of a region to improve the mechanisms of the elements interaction in the system of the regions' ecological and economic advantages.

\section{Results and discussions.}

Economic behaviour of regions should be focused at raising of the region's competitiveness by preservation and rational usage of the available competitive advantages as well as creation of the new ones. The competitive advantages set in the base of the region's ecological and economic competitiveness are connected with the certain territory and serve the basis for creation of the favourable position in the competitive area of the state aimed at involvement of the region's population, authority bodies, businessmen and investors to provide a balanced social, economic and ecological development of the region.

To improve the mechanisms of the elements interaction in the system of the regions' ecological and economic competitive advantages it is proper to consider a region's competitive potential as a system, which is characterized by some amount of available economic, ecological and other advantages. In this the competitiveness of regions is a system characteristic feature. To the main elements of the ecological and economic competitive potential as a system we refer: competitive potential of a region, sources and factors of the regional competitiveness, ecological and economic competitive advantages, competitive positions and competitive status of a region (Fig. 1). 


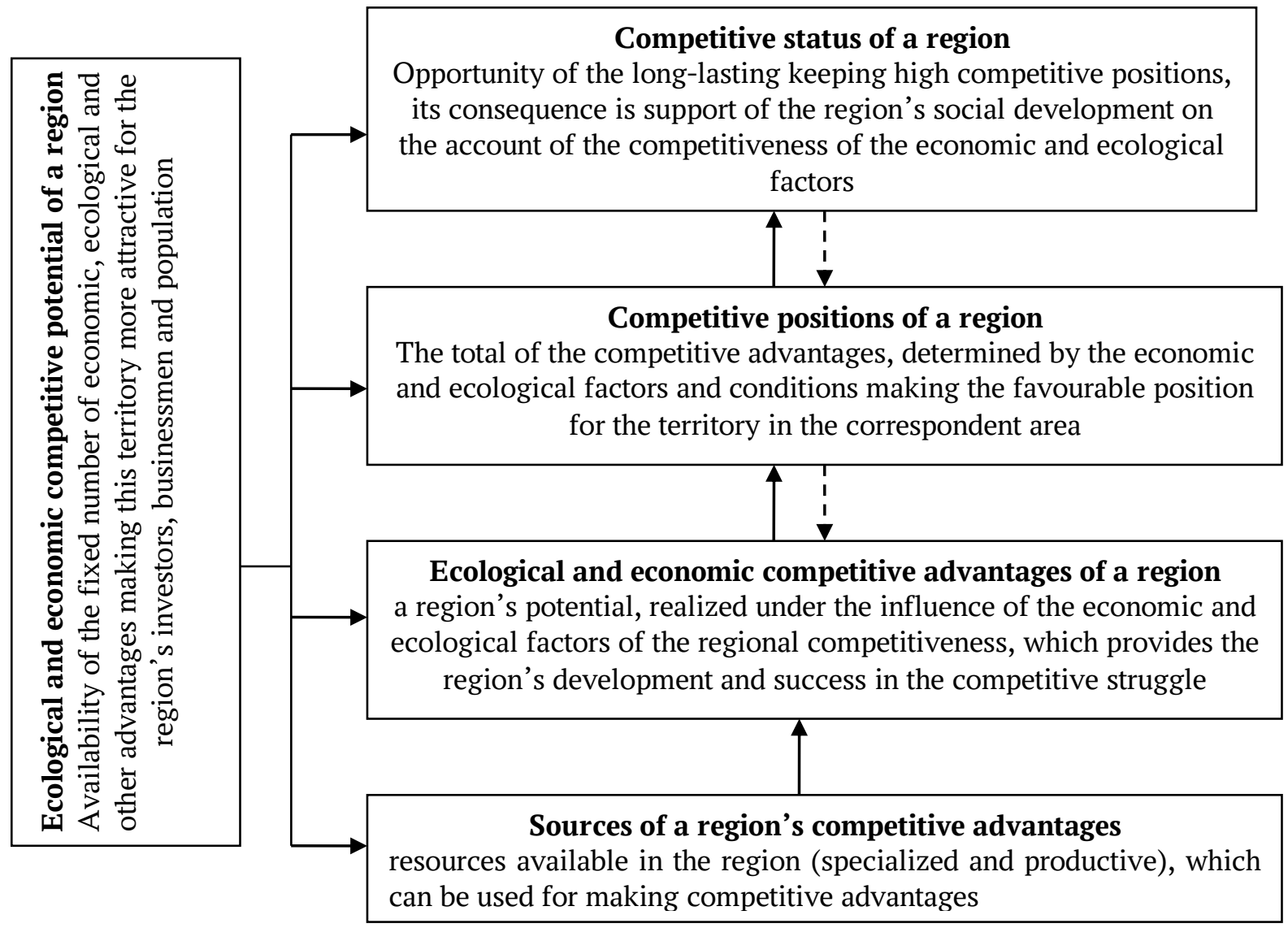

\section{Fig. 1. Structural elements of the regions' ecological and economic competitive potential system}

Source: developed by the author.

Ecological and economic competitiveness of regions is conditioned by the availability and development level of the competitive potential constituents, to which we refer the following components and indicators characterizing them according to the logic of our research (Table 1).

The state of the competitive potential is influenced by various factors, giving advantages as well as restricting regions' opportunities in the competitive struggle. Accordingly, the next element of the ecological and economic potential is factors of competitiveness.

In the scientific sources there are different approaches to classification of the regions' competitiveness factors. We can give an example of classification made by N. A. Grineva as the most characteristic approach. Due to it the competitiveness factors are divided according to the sources of for- mation (main and developed) and according to the influence type (factors of external and internal influence) (Grineva, 2008, p. 104).

Another approach to the factors classification is given in the works of Sh. I. Shakhabov, who determines two groups of a region's competitive potential factors: structural factors (effective infrastructure, sufficient proposition of the state services, high quality of the life environment and effective regional policy) and functional ones (existing opportunities for business placement, concentration of the innovation activity, development of communication networks and transit logistic hub, involvement of foreign investments) (Shakhabov, 2010).

Belorusian scientist A. A. Shashko proves that management of the regions' competitiveness is conditioned by the influence of three groups of factors: stabilizing (organizational and economic mechanisms, social and 
economic situation, financial and economic activity of the enterprises in the region's territory); infrastructural (development of the market structure and the region's institutional system, correlation of demand and consump- tion, legislative security and others) and stimulating or activating (a system of the government orders, distribution of quotas among regions, credit and tax privileges and others) (Shashko, 2012, p. 108).

\section{Table 1. Constituents characteristics of the ecological and economic competitive potential of regions (EECPR)}

\begin{tabular}{|c|c|c|c|}
\hline \multirow{2}{*}{$\begin{array}{l}\text { Constituents of } \\
\text { EECPR }\end{array}$} & \multirow{2}{*}{$\begin{array}{l}\text { Characteristics of the } \\
\text { EECPR components }\end{array}$} & \multicolumn{2}{|c|}{ Exponents of the region's competitive potential } \\
\hline & & Economic & ecological \\
\hline $\begin{array}{l}\text { Natural } \\
\text { sources }\end{array}$ & $\begin{array}{l}\text { Implies available natural } \\
\text { resources advantages, } \\
\text { formed on the basis of the } \\
\text { availability and usage of the } \\
\text { production factors }\end{array}$ & $\begin{array}{l}\text { Territory area of the region per inhab- } \\
\text { itant; availability and composition of } \\
\text { the raw material resources, which are } \\
\text { extracted on the territory of the } \\
\text { region, infrastructural support of the } \\
\text { region }\end{array}$ & $\begin{array}{l}\text { Availability of recreational } \\
\text { resources, level of wastes for- } \\
\text { mation, neutralization of pol- } \\
\text { lution from the stationary } \\
\text { sources }\end{array}$ \\
\hline Productional & $\begin{array}{l}\text { Characterizes the quantita- } \\
\text { tive and qualitative aspect } \\
\text { to perform the economic } \\
\text { activity }\end{array}$ & $\begin{array}{l}\text { Output of gross market product; out- } \\
\text { put of industrial and agricultural pro- } \\
\text { duction according to branches and } \\
\text { kinds of production; retail turnover; } \\
\text { number of the business activity sub- } \\
\text { jects }\end{array}$ & $\begin{array}{l}\text { Share of ecological products } \\
\text { in the general output, a share } \\
\text { of high technology products } \\
\text { producers, usage level of eco- } \\
\text { logical technologies }\end{array}$ \\
\hline Human & $\begin{array}{l}\text { Includes labour potential } \\
\text { and potential of life quality } \\
\text { for the region's population }\end{array}$ & $\begin{array}{l}\text { Number of population, coefficient of } \\
\text { the population natural growth; num- } \\
\text { ber of people involved in economics; } \\
\text { monthly average pay }\end{array}$ & $\begin{array}{l}\text { Diseases level of the popula- } \\
\text { tion because of the ecological } \\
\text { pollution }\end{array}$ \\
\hline $\begin{array}{l}\text { Organizational- } \\
\text { managing }\end{array}$ & $\begin{array}{l}\text { Characterizes ability of the } \\
\text { regional authorities to mo- } \\
\text { bilize factors of the regions' } \\
\text { development and organize } \\
\text { cooperation of the targeted } \\
\text { groups in the local commu- } \\
\text { nity }\end{array}$ & $\begin{array}{l}\text { Migration movement of the popula- } \\
\text { tion; number of subjects of small and } \\
\text { middle business registered at the ter- } \\
\text { ritory; share of profitable enterprises } \\
\text { in the general quantity }\end{array}$ & $\begin{array}{l}\text { A number of ecological pro- } \\
\text { grammes, realized per year, } \\
\text { budget support for financing } \\
\text { of the ecological } \\
\text { consequences, profits from the } \\
\text { ecological taxes and charges }\end{array}$ \\
\hline $\begin{array}{l}\text { Investment- } \\
\text { innovational }\end{array}$ & $\begin{array}{l}\text { Characterizes availability } \\
\text { and formation of economic, } \\
\text { organizational and political } \\
\text { and legal preference for } \\
\text { conducting business }\end{array}$ & $\begin{array}{l}\text { Investments in the basic capital per } \\
\text { inhabitant; share of the region's own } \\
\text { costs in the general amount of in- } \\
\text { vestments; cash financial result per } \\
\text { hired inhabitant; share of the innova- } \\
\text { tional enterprises in the general } \\
\text { amount }\end{array}$ & $\begin{array}{l}\text { Investments directed at } \\
\text { preservation of the environ- } \\
\text { ment }\end{array}$ \\
\hline
\end{tabular}

Source: developed by the author.

Evaluating the approaches mentioned above, one can assert that that any of them is substantial within the limits of the researches performed by the scientists. Their rational combination gives an opportunity to synthesize one's own consideration of system of factors which condition the regions' ecological and economic attraction for particular sectors and types of activity, define functions which potentially can be performed by separate regions.

On the basis of studying Ukrainian and foreign views on factors forming regions' competitiveness the author's classification of factors is offered. It consists of the following five complex groups of factors defining the ecological and economic competitive potential of regions:

1. Resource (basic) factors - a group of factors which characterize natural resource constituent of the ecological and economic competitiveness of the regions' potential (see table 1), taking into account the resources and factors of production accumulated during long-lasting time period (in particular those formed in soviet time). 
2. Infrastructural factors - a group of factors which characterize the basic, engineering, innovational-technological and social infrastructure.

3. Institutional factors - a group of factors which include the total of the state management apparatus institutions, expenditure on organization and maintenance of the money-credit and financial system (market infrastructure); legal environment; institutional system.

4. Management factors - a group of factors reflecting the state and quality of the regional management.

5. Functional factors - a group of factors which characterize the level of performing managing functions concerning support of the region's ecological and economic development.

An expert evaluation, organized in a selective way, has been performed to evaluate the influence degree of factors on the ecological and economic competitiveness of regions differentiated according to the logic of our research,. The leading specialists (the length of the state service was not less than 5 years) have been chosen as the experts of the regional authorities, namely regional state administrations of Ukraine's regions, who were asked to fill the developed questionnaire form. Taking into account impossibility to involve in the research the representatives of all 27 regions determined by the Constitution of Ukraine, there were some difficulties in conducting the total research. Thus it was decided to organize 33\%-non-selective observation, i.e. 9 questionnaire were selected to the sample, chosen by random. Evaluation of the significance level of separate factors was performed according to the 5-point grading scale. After the processing of the questionnaire results, the following system of factors of the ecological and economic competitiveness of Ukraine's regions has been obtained (Table 2).

Table 2. System of factors of the ecological and economic competitiveness of Ukraine's regions

\begin{tabular}{|c|c|c|c|}
\hline $\begin{array}{l}\text { Group of fac- } \\
\text { tors }\end{array}$ & $\begin{array}{l}\text { Elements } \\
\text { of impact }\end{array}$ & Factors & $\begin{array}{l}\text { Impact } \\
\text { degree }\end{array}$ \\
\hline \multirow[t]{2}{*}{ Managing } & Economic & $\begin{array}{l}\text { Succession of the support policy in development enterprises; } \\
\text { development of the state-private partnership; institutional } \\
\text { flexibility of the economic policy; quality of the investment } \\
\text { environment; support level of the innovational programmes; } \\
\text { effective budget policy }\end{array}$ & Substantial \\
\hline & Ecological & $\begin{array}{l}\text { Policy of ecological business support; following the adminis- } \\
\text { trative control of the ecological safety }\end{array}$ & Substantial \\
\hline \multirow{2}{*}{ Functional } & Economic & $\begin{array}{l}\text { Performance of the functions in the economic development of } \\
\text { the region }\end{array}$ & Substantial \\
\hline & Ecological & Support of the ecological safety in the region & Substantial \\
\hline \multirow[b]{2}{*}{ Resource (basic) } & Economic & $\begin{array}{l}\text { Level of the industry development; availability of the quali- } \\
\text { fied labour force; creative potential of the population and level } \\
\text { of the business culture }\end{array}$ & Moderate \\
\hline & Ecological & $\begin{array}{l}\text { Geographical position and natural-climatic conditions, availa- } \\
\text { bility of the recreational resources; negative influence of in- } \\
\text { dustry and living activity of the population on the ecological } \\
\text { state of the region }\end{array}$ & Moderate \\
\hline Infrastructural & $\begin{array}{l}\text { Economic, } \\
\text { ecological }\end{array}$ & $\begin{array}{l}\text { Basic infrastructure; engineering infrastructure; innovational- } \\
\text { technological infrastructure; social infrastructure. }\end{array}$ & Moderate \\
\hline \multirow{2}{*}{ Institutional } & Economic & Legal environment; institutional system & Insignificant \\
\hline & Ecological & Legal ensurance of the ecological activity & Insignificant \\
\hline
\end{tabular}

Source: developed by the author. 
The distinctive feature of the presented classification as compared with the existing ones is the complex reflection of all groups of factors defining the ecological and economic competitive potential of regions. There is also a possibility to range factors of competitiveness according to the degree of influence on the economic and ecological constituents. The presented classification shows that the factors of the ecological and economic competitiveness can influence at the regional level the life support conditions of the citizens, activity of organizations and provide effective state management, meanwhile the influence on some factors is restricted by the set state and regional powers.

Competitiveness of regions is realized via regional advantages, in the limits of the given research they denote the realized potential of the region under the conditions of economic and ecological factors, which provide the development of the region and success in the competitive struggle.

Formation of the competitive advantages directly depends on usage of the specialized and productive sources of the competitive advantages, which denote the region's available resources, that can be used for creation of the competitive advantages. Fig. 2 shows the stages of transformation of the competitive advantages sources into the positive dynamics of the region's competitiveness exponents, correspondent procedures and realization instruments.

The process of transformation of the competitive advantages sources into positive dynamics of the regions' competitiveness level includes: the stage of detection of the sources of the region's competitive advantages; the stage of formation of the competitive advantage; the stage of realization of the competitive advantage on the internal regional, national or international markets; the stage of evaluation of the region's competitiveness level dynamics. At the stages of formation and realization of the competitive advantage there takes place the choice of the correspondent methodical, administrative or market instruments.

Thus, before the source of the competitive advantage becomes the direct competitive advantage of a region it should be detected, used for the formation of the competitive advance and realized in the form of a competitive product. On the stage of formation of the regions' competitive advantage the sources of the competitive advantage are involved to the production process with the purpose to create the competitive products and technologies by means of them. On the stage of realization of the regions' competitive advantages the formed competitive product comes to the market. On the last stage the dynamics of the region's competitiveness level is evaluated: existence of the competitive advantage in the region is shown by positive dynamics of exponents, which evaluate the level of its competitiveness.

The quality of the given sources, in their turn, depends on the availability of the region's specialized educational institutions, scientific laboratories, development institutions, scientific-research centers. The availability of the extra basic sources of the competitive advantages is not always the sufficient condition for the region to receive the competitive advantage in the interregional competition. Therefore the state can essentially influence the formation of the necessary sources of the competitive advantages on the account of financing and reforms, making favourable national environment.

Thus, determination of the ecological and economic competitive potential of a region as a system, determination of the basic structural elements in the given system enabled to make the conceptual scheme of the elements interaction in the system of the region's ecological and economic competitive potential (Fig. 3). 
Andrusyak N. O. Mechanisms of elements interaction in the system of ecological and economic regional competitive advantages

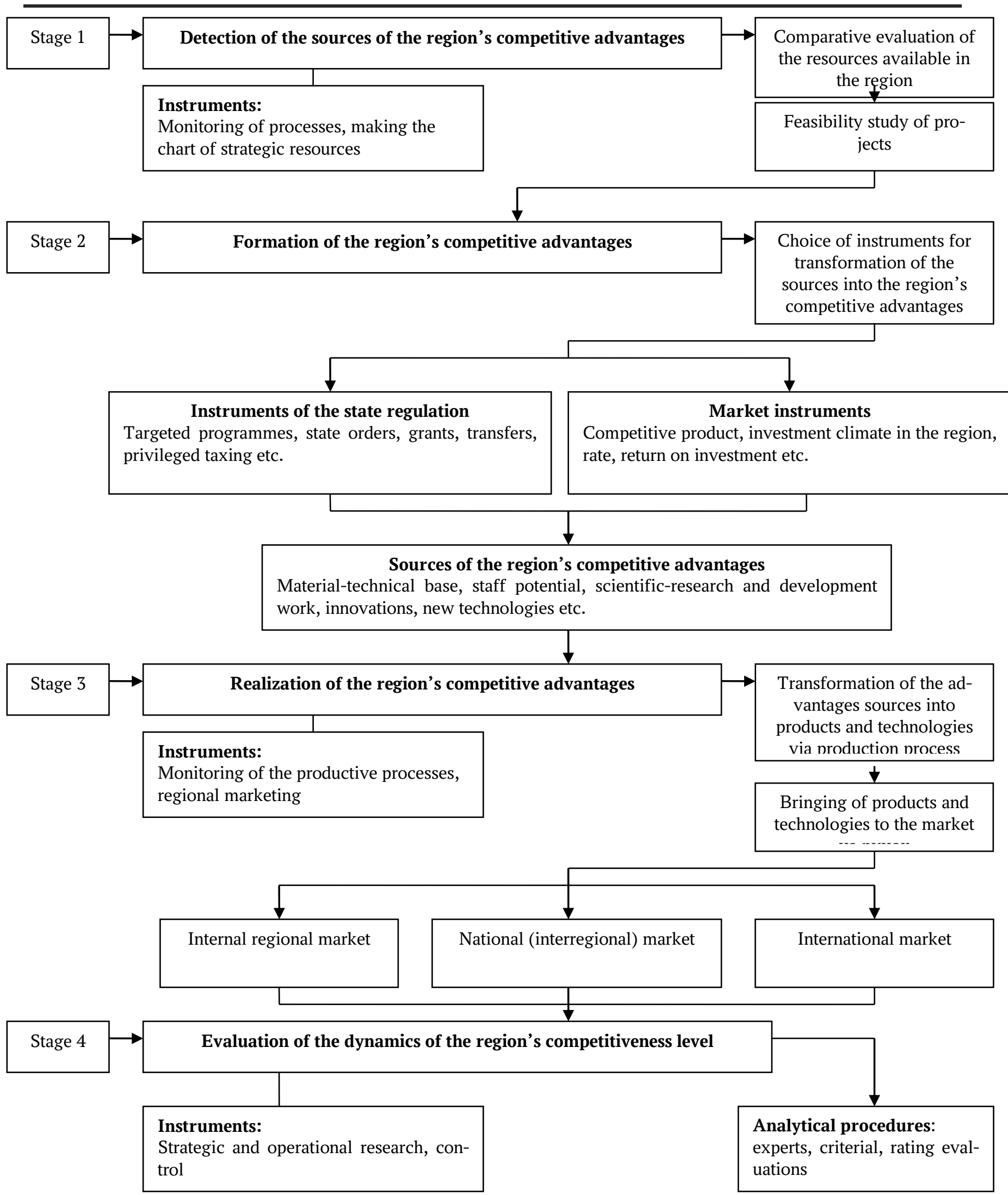

Fig. 2. Stages of transformation of the competitive advantages sources into the positive dynamics of the region's competitiveness level

Source: developed by the author. 


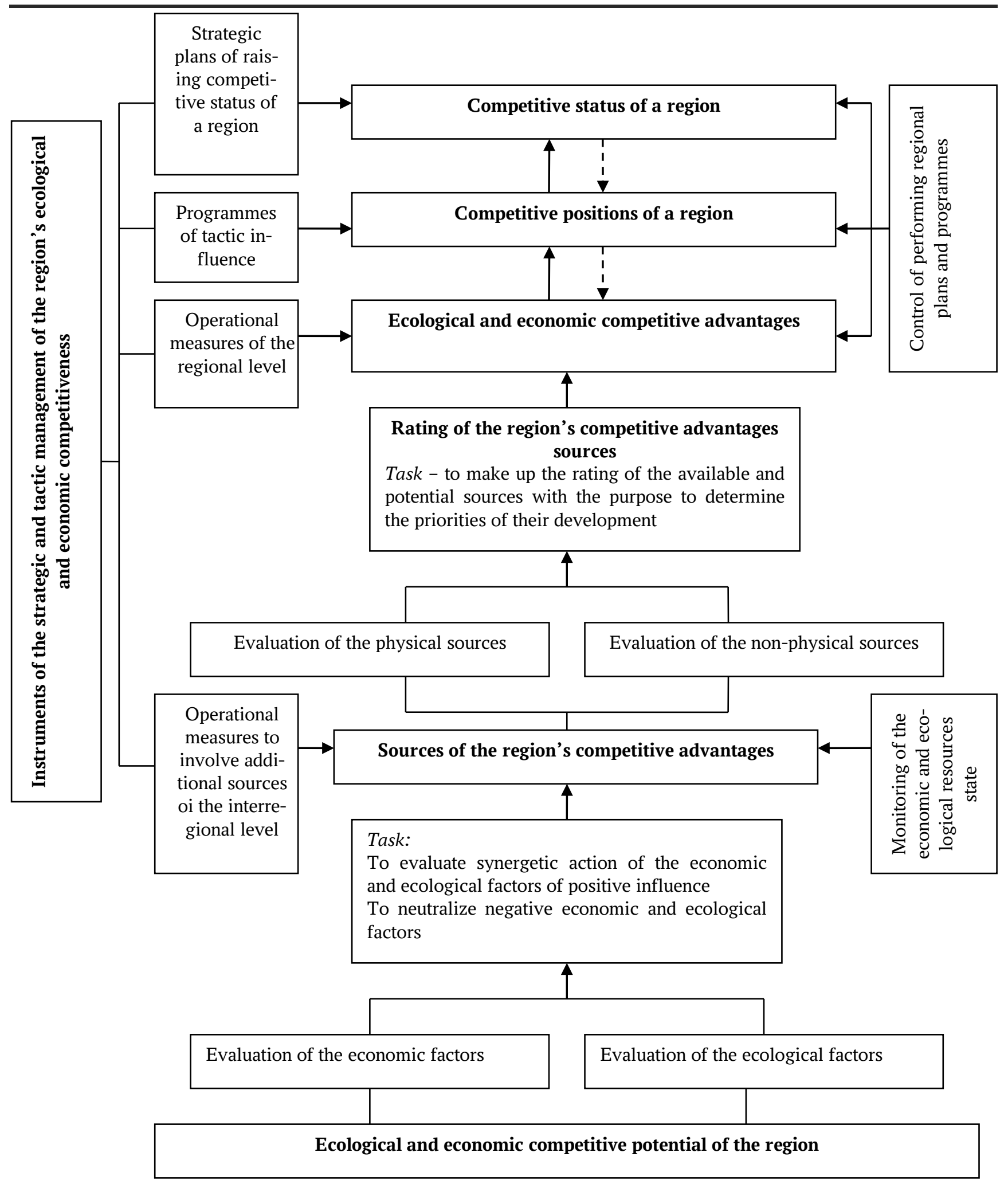

\section{Fig. 3. Conceptual scheme of the elements interaction in the system of the ecological} and economic competitive advantages

Source: developed by the author.

The offered scheme allows to trace, how of ecological and economic competitive ada region's ecological and economic competi- vantages by means of economic and ecologitive potential is transformed into the sources cal factors of the regional competitiveness, 
and how ecological and economic competitive advantages themselves, which are the basis of the competitive positions of the region, are formed from these sources. Stable longlasting competitive positions provide the competitive status of the region. In this the author shows the interrelation of the competitive advantages and competitive status, since not only competitive advantages are the basis of the region's competitive status, but also the competitive status in its turn is the condition to realize ecological and economic competitive advantages.

There are targeted instruments of the strategic and tactic management of the region's ecological and economic competitiveness for the region to reach the high competitive status on every element of the regional ecological and economic competitiveness, with the exception of the competitive potential. They consist of strategic plans on raising the regions' competitive status, programmes of the tactic influence, operational measures of the regional level and operational measures on the involvement of additional sources on the interregional level. Realization of the mentioned actions will contribute to the transformation of the sources of competitive advantages into the ecological and economic advantages causing stable competitive positions of a region and its competitive status.

\section{Conclusions.}

The offered conceptual scheme allows to trace, how the potential ecological and economic opportunities of regions via economic and ecological factors of the regional competitiveness are transformed into the sources of the competitive advantages, and how ecological and economic competitive advantages are formed from these sources. They become the basis of the region's high competitiveness, aimed at realization of the key purpose - to raise the level and improve the life quality of the regions' population. Study research of the strategic and tactic instruments for managing ecological and economic competitiveness of a region requires further research.

\section{References}

Bagrova, I. V. (2007), “Components and factors of competitiveness”, Bulletin of economic science of Ukraine, no. 1 , pp. 11-16.

Bilenkyi, P. Yu. (2005), Faktory i mekhanizmy zabezpechennya konkurentospromozhnosti rehionu [Factors and mechanisms of ensuring the competitiveness of the region], Institute for Regional Studies, NAS of Ukraine, Lviv, Ukraine, 145 p.

Gerasymchuk, Z. V. and Kovalska, L. L. (2008), Konkurentospromozhnist' rehionu: teoriya, metodolohiya, praktyka: monohrafiya [Competitiveness of the region: theory, methodology, practice: monograph], Nadstyrya, Lutsk, Ukraine, 248 p.

Grineva, N. A. (2008), "The main categories and concepts of competitiveness at various levels of the hierarchy of socio-economic systems", Scientific works of DonNTU. Series: Economics, 2008, no. 35, pp. 103-107.

Nazarov, M. I. (2013), “Competitiveness of the region: essence and properties”, Efektyvna ekonomika, no. 10, URL: http://www.economy.nayka.com.ua/?op=1\&z=2438 (Accessed 25 March 2019).

Rastovtseva, S. N. and Grineva, N. A. (2014), Konkurentosposobnost' regiona v usloviyakh globalizatsii [Competitiveness of the region in the context of globalization], CONSTANT, Belgorod, Russia, $187 \mathrm{p}$.

Romanko, O. P. (2015), “The concept of competitiveness of a region and its characteristics", Efektyvna ekonomika, no. 3, URL: http://www.economy.nayka.com.ua/?op=1\&z=3869 (Accessed 25 March 2019). 
Andrusyak N. O. Mechanisms of elements interaction in the system of ecological and economic regional competitive advantages

Chertok, K. M. and Goncharenko, T. P. (2013), "The essence of the concept of regional competitiveness", Economy, no. 2, URL: http://www.rusnauka.com/6 PNI 2013/Economics/2 129 298.doc.htm (Accessed 25 March 2019).

Shakhabov, Sh. I. (2010), "Conditions for the formation of competitiveness of geographically organized economic systems", Management of economic systems, no 24, URL: http://www.uecs.ru/regionalnayaekonomika/item/251-2011-03-24-12-12-58-44 (Accessed 25 March 2019).

Shashko, A. A. (2012), "Innovative development and competitiveness of the regions of the Republic of Belarus", The interaction of business, government, science: a three-sided view of economic development, collection of research and discussion materials, vol. 1, pp. 79-125.

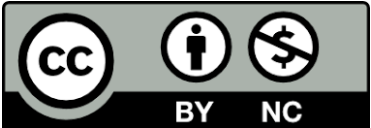

ЦейтвірліцензованонаумовахЛіцензії Creative Commons «ІзЗазначеннямАвторства Некомерційна 4.0 Міжнародна» (CC BY-NC 4.0). Thisisanopenaccessjournalandallpublishedarticlesarelicensedunder a CreativeCommons"Attribution-NonCommercial 4.0 International" (CC BY-NC 4.0). 